Миливоје В. МЛАЂЕНОВИЋ*

Универзитет у Новом Саду Педагошки факултет Сомбор
Оригинални научни рад

Примљен: 29. 11. 2020.

Прихваћен: 25. 2. 2021.

\title{
СРПСКА ДРАМСКА КЬИЖЕВНОСТ ЗА ДЕЦУ У ЖАНРОВСКОМ СИСТЕМУ
}

\begin{abstract}
Полазећи од дефиниције драме за децу као драмско-сценске структуре која је по свом језику и садржају приступачна, односно намењена деци различитог узраста, у раду се разматрају и класификују дела српске драмске књижевности за децу у жанровском систему. Разврставање је извршено према форми дијалога, према узрасту којем су дела намењена, према типу и начину збивања која су у драми приказана, те естетском деловању на публику. У идентификацији и типологизацији драмских дела за децу уважена су такође различита мерила везана за природу драмског збивања и личности у драми: дужина драме, намена, број личности, као и према медијима у којима се појављују (драмска представа за децу у позоришту, луткарска представа, радио-драма за децу, телевизијска драма за децу, филм за децу, сценско-музички облици, итд.). Посебна пажња указаће се на специфичне облике драмских текстова за децу, драматизована прозна и поетска дела, али који нису пука прилагођавања текста за сцену, него ново драмско дело. У том погледу посебна пажња обратиће се и на преобликовање модела бајке као посебан вид драматизације. У закључку се констатује да проучавање драме за децу, сагледавање развоја, њено разврставање и оцена нису у складу са местом које овај жанр има у стваралаштву за децу и заостају за критичком рецепцијом других литерарних подручја.

Кључне речи: драма, драма за децу, жанр, жанровски систем, класификација, позориште, публика.
\end{abstract}

Термин „систем” у овом раду употребљен је као оквир у коме се драма за децу осветљава у историји српске књижевности, тежња да се установи њихов поредак, начела организовања, да се опише тај жанр и поджанрови, модалитети, његова обележја, као и везе са другим жанровима. Могуће је конституисати жанровски систем драме за децу који би подразумевао избор, распоред и односе међу доминантним жанровима у некој књижевној епохи или раздобљу. „Замисао жанровског сустава полази од претпоставке да се називом 'жанр' може означити на некој, углавном најнижој разини, класификаторски појам који окупља препознатљиво слична књижевна дјела, а да сва-

\footnotetext{
*milivoje_mladjenovic@yahoo.com
} 
ка књижевна епоха, раздобље, па у некој мјери и књижевни правац, увјетује распрострањеност, популарност и претпостављену књижевну вриједност неких жанрова" (Солар 2007: 400). Класификовати обавезно значи концептуализовати, значи уопштавати. У нашем случају то би подразумевало да се драме за децу из наше баштине, преведене драме, драматизације одговарајућих књижевних остварења и нова драмска дела намењена категорији читалаца дечјег и омладинског узраста, издвоје у посебан круг драмских текстова за које се устаљује жанровски назив „драма за децу”. Кад је реч о критеријумима за поделу драмских жанрова, у теорији књижевности једва да се помиње специфични облик који се односи на животну доб. Прошири ли се овом карактеристиком основна дефиниција драме, добија се ближе одређење: драма за децу је драмско-сценска структура која је по свом језику и садржају приступачна, односно намењена деци различитог узраста. Основу за такво класификовање пружа полазиште Велека и Ворена да „жанр треба (...) схватити као облик груписања књижевних дела теоријски заснован како на спољној форми (одређени метар или структура), тако и на унутрашњој (став, тон, сврха - грубље речено, предмет и публика)" (Велек, Ворен 1985: 270). У класификацији књижевности појам жанра има значење књижевне врсте или рода, одређујући појмове који су установљени традицијом. „У сваком добу поред језгра истоветних одлика истовремено постоји и доста велики број других својстава за која се сматра да су мање важна и да стога нису од одлучујуће важности да би одређено дело било сврстано у неки други жанр. Према томе, зависно од тога које се својство његове структуре сматра важним, једно дело може да буде сврстано у различите жанрове" (Тодоров 1986: 73).

Драма за децу је такође подложна и жанровском одређењу историјског националног типа па се може говорити и о жанру српске драме за децу. Овај историјски жанр може бити и представник по аналогији изведене логичке класе по њиховим тематским или формалним сродностима и емпиријске групе по њиховом релативном јединству извора (бајковито, лирично, музичко у драми за децу, итд.). То значи да драма за децу задржава општа својства драме, али да садржи и извесне своје карактеристике. „Жанр је описан исказ о извесном броју међусобно сродних дела" (Гиљен 1980: 110). Често у драмској књижевности за децу препознајемо поједине текстове, групе или низове текстова у улози предложака. То су, у српској књижевности, најчешће бајке, приповедни клишеи, стереотипи који су у новонасталом тексту, пре свега, у интертекстуалном, односно цитатном односу. „Па, ипак, свођење драме намењене деци искључиво на бајку веома је једнострано”, сматра Слободан Ж. Марковић, „не само зато што њене извођаче, сталним играњем у истој врсти, нагони на шаблон, него пре свега зато што је спектар интересовања дечје публике далеко шири (...). Отуда не треба да нас изненади закључак да драмски писац који се обраћа дечјој публици нема никаквих 'жанровских“ ограничења и да може слободно да бира ону форму која највише одговара материји коју обрађује" (Марковић 2003: 6). Мора се свакако, кад је реч о драми за децу у жанровском систему, имати у виду и Калерова „књижевна компетенција” (в. Калер 1975), која подразумева ,ауторово и читаочево овладавање 
одговарајућим литерарним конвенцијама и репертоарима" (Јуван 2013: 141). Тако Калер увођењем појмова компетенција уводи и појам интертекстуалности с намером да докаже да жанр у свести читалаца и писаца као хоризонт очекивања функционише тек преко интеретекстуалности (Јуван 2013: 142). Тодоров запажа да „у сваком добу известан број књижевених типова постаје толико познат читаоцима да се ови њима служе као кључевима „за тумачење дела: у том случају књижевни жанр остаје према речима X. P. Jayca видокруг очекивања” (Тодоров 1986: 73). Књижевни жанр постаје „модел писања". Другим речима, књижевни жанр је тип који је конкретно постојао у историји, који је био део књижевног система једног доба" (Тодоров 1986: 73). Традиционална подела у области драме почива на „доминантној емотивној вредности, и са њом повезаног карактера представљене стварности (трагедија, комедија, фарса, мешане и посредне врсте) и поделе „засноване на реализационој намери (позоришно дело, опера, филм, драма за читање)” (Маркјевич 1974: 143).

Тако се, као посебна подгрупа драмске књижевности, образовао скуп драма за децу насталих преобликовањем бајке. И то су, у српској драмској књижевности за децу, најуспелије драме. Ако се бајка не може лако пронаћи, може се рећи да се она заправо развила до непрепознавања. Понегде само фрагменти доказују бајковно порекло драме. У неким драмама за децу делују „удружено” фрагменти различитих бајки. Они се некад крију већ у наслову који не асоцира на бајковно порекло, али постоје и примери директне везе наслова драме са бајком, иако се њихов садржај уопште не дотиче бајковног наслеђа. Надаље, ваља обратити пажњу на улогу појединачног жанровског система у општој хијерархизацији књижевних форми, јер књижевне форме настају на различите начине: поетичким чином, модификацијом нечега што је већ раније постојало, или некако другачије. Све ниже класе књижевних форми настају накнадном интерпретацијом основних модела врста, па је могуће пратити њихово порекло и утицај појединих система на њихов настанак и даљи живот. Драма за децу на основу бајке настала је тако што је један жанровски систем (драма) на одређени начин интерпретирао моделе другог система (бајке) (в. Млађеновић 2009). Дела у овој групи се међусобно разликују: а) према форми дијалога (проза, поезија, и проза и поезија), б) према узрасту којем су намењена (деца предшколског узраста, деца у нижим разредима основне школе, итд.), ц) према приступу обради материјала бајке (доследно поштовање сижеа, одступање од сижеа, временско и просторно одређивање збивања новонастале форме итд.), д) према типу збивања које приказује, начином збивања и естетским деловањем на публику (комедија, драма, мјузикл).

У складу с Велековим и Вореновим упозорењем да је драма још мешовита уметност „која обухвата и 'спектакл' користећи се глумчевом и редитељевом вештином, занатом костимографска и електричара" (Велек, Ворен 1985: 267), а имајући у виду њихову „књижевносност”, класификацији измичу форме које намеће нови медији. Слободан Ж. Марковић такође налази да је технолошки напредак средстава за комуникацију и нових медија утицао 
да се појаве и нови жанрови, односно поджанрови, са наглашавањем њихових специфичности у називу: драмски текстови за луткарско извођење, радио-драма за децу, сценарио филма за децу, тв драма за децу, мјузикл за децу, монодрама за децу, сценско-музички, фестивалски и карневалски облици и друге форме. По учесталости и сродности са драмском књижевношћу издвајају се драмски текстови за луткарско извођење (уобичајено називано луткарско позориште) и радио-драма за децу. Српско луткарско позориште у периоду после Другог светског рата прихватило је драматургију, изражајна средства и манире драмског театра. Као почетак краја доминације драмског позоришта у луткарству бележи се 1958. година. Настало је удаљавање од конкретног људског, али не и од људског уопште. Људско је остало садржај луткарства, али тако уопштено да је изгубило конкретне људске форме и преузело форме изражавања лутке. Радио-драмски жанр је временом стекао своју независност, следбенике и публику, своју естетику која је прилагођена, односно условљена предностима и ограничењима медија којем припада.

Надаље, драматизације књижевних дела за децу (басна, бајка, приповетка, роман, циклус песама, поема) и слично су такође веома учестала појава у српској драмској књижевности за децу и могу се одредити као посебан жанровски вид. Драматизације су специфична појава, јер се јављају у различитим варијантама: од прилагођавања текста за сцену до преузимања теме и мотива на којима се инспирише и ствара ново драмско дело (Кад је био мрак у адаптацији М. Кречковића, Капетан Џон Пиплфокс Д. Радовића у драматизацији Мирослава Беловића, итд.). Стога се ови драмски облици могу издвојити у посебну класу, али се зависно од удела иновативног, стваралачки оригиналног приступа истовремено могу посматрати и као аутентичне драме за децу које могу бити сврстане у друге поджанрове, следствено њиховим унутрашњим својствима.

То показује да су могуће различите врсте разграничења у драмској књижевности за децу. Границе између група (драмске бајке, нпр.) и класа (драма) прилично су нестабилне. Условљене су различитим жанровским факторима. „Жанровско јединство се „не своди на ауторско јединство, јер аутор као физички и морални појединац, није једини емпиријски 'извор' који би био у стању да одреди јединство групе дела" (Женет 2002: 50). Исто тако се опусу неког аутора понекад (више или мање) може приписати доминантно жанровско одређење. Љубивоје Ршумовић је песник и поред његовог драмског стваралаштва за децу, Игор Бојовић је драмски писац за децу и поред његовог драмског опуса за одрасле, Александар Поповић је драмски писац за децу иако пише и романе за децу, као и Душан Радовић, који је доминантно песник, итд.).

Специфичном положају драмске књижевности за децу доприноси и њена двострукост: она припада области књижевности за децу, али истовремено је по свом устројству и део српске драмске књижевности у целини. И није ту крај њеној двострукости: драма за децу обитава у две сфере уметности: књижевно-језичкој и позоришној које, у овом случају, једва могу да се раздвоје. Овакав положај извесно утиче и на њен статус. Врло је могуће да 
ова парцијализација, делимична припадност различитим књижевним и уметничким подручјима утиче на то да се до сада није указала целина драмске књижевности за децу. При томе не би требало сметнути с ума ни потпуно огољену, врло прагматичну примену драмске књижевности у педагошке сврхе, која се уобличава у специфичан драмски метод и образовање за позориште.

Расправа о савременој српској драмској књижевности за децу, обавезује и на говор о историји овог жанра. Међутим, поузданијих, прегледнијих, конзистентнијих студија из ове области је сасвим мали број. Нажалост, врло мало се непосредно зна о зачецима драме за децу (радови С. Ж. Марковића, Б. Крављанца, љ. Ђокића, Н. Вуковића у том су погледу драгоцени) тако да се драма за децу у српској књижевности једва и конституисала као књижевно-теоретски појам. Ниједна енциклопедија не садржи одредницу „драма за децу” или „драмска књижевност за децу”. Отуда не чуди да се драма за децу доживљавала као нешто што је проистекло из непосредне педагошке праксе, или, евентуално, забаве. У књижевно-историјском погледу је важан и учинак Бранислава Крављанца. Иако писано као предговор за Антологију српске драме за дещу, ово разврставање имена, наслова, група, покрета, и утицаја, има одлике периодизације једног специфичног књижевног облика унутар српске књижевности за децу, јер већ и избор аутора образује систем жанрова. „Нормативни системи или 'идеални простори“ књижевности, несумњиво је, често су се образовали око неког грозда 'великих аутора', од којих би сваки заузимао место које је обично додељивано неком посебном жанру” (Гиљен 1980: 352). Крављанац је бирајући драмске и луткарске текстове тежио ка томе да оформи слику целине развоја српске драмске књижевности, њеног континуитета и садржајне, жанровске и формалне разноликости. Уважавајући друштвено-историјску условљеност настанка драмских дела за децу и њихову књижевно-драматуршку вредност, Бранислав Крављанац је цео развојни ток овог жанра у српској књижевности поделио на четири раздобља. Велика скепса према „есенцијалистичким периодизацијским концептима” (Бити 2000: 366), између осталог и због успона нових медија „и нових жанровских концепата омета класификацијски посао.

У првом раздобљу је комад Добродетељни дервиш или Звекетуша капа Јоакима Вујића који је, иако није писан за децу, имао снажну рецепцију код дечје публике, као и Стеријин Волшебни магараи, који такође није намењен деци. У овај период уврштена је и Несрећна Кафина Јована Јовановића Змаја, значајна и као први текст за луткарску позорницу. Почетак другог периода, од 1903. до почетка Другог светског рата, обележава једночинка Наша дец̧а II (1903) Бранислава Нушића а крај раздобља означава Пепељуга Живојина Вукадиновића. Границе трећем периоду Крављанац ставља у 1944. односно 1994. годину (до смрти Стевана Пешића). У првом развојном кругу (1944-1954) аутор, осим неколико прерада и ,једва два-три каква-таква оригинала", не налази значајнијих вредности у епохи доктринарног оптимизма. У другом развојном кругу (1954-1966) настају модерни драмски текстови за децу - комична сценска бајка Љубише Ђокића У цุара Тројана козје уши и 
романтична бајка истог аутора - Биберче. Придодајући каснију појаву Бајке о цุару и пастиру (1958) Бошка Трифуновића и Пепељугу (1966) Алекандра Поповића, Крављанац добија аргументацију за своје тријадно жанровско одређење српске драмске књижевности за децу: романтичну, комичну и ироничну врсту. Ову етапу одликује и настанак првих модерно писаних луткарских сценских текстова (Звезда Фифи Драгана Лукића, На слово, на слово Душана Радовића, Чудесни виноград Стевана Пешића) те драмски текстови Миодрага Станисављевића Царев заточник, Немушти језик и Зачарана принцеза са измењеним обрасцем: бајка постаје „шантава прича”. Тиме се управо потврђује да је бајка преобликована ${ }^{26}$. Игор Бојовић такође расклапа традиционални образац бајке (Мачор у чизмама, Баш Челик, Лепотииа и звер), обликујући је у складу са савременом драмском поетиком. Крављанчева периодизација је поуздан преглед драмске књижевности за децу у двадесетом веку. Када јој се придода преглед драмских облика за децу у прве две деценије XXI века која имају обележја постмодернистичке интерпретације, добије се сублимна резултанта традиције драме за децу која траје скоро два века.

Диференцијација драмских жанрова је веома еластична. Такву слободу обилато користе сами ствараоци при жанровском означавању дела властитим аутопоетичким одредницама. Писци су ближе жанровско одређење формулисали уз уважавање критеријума везаних за природу драмског збивања и личности у драми, дужину драме, намену, број личности, употребу прозе и поезије, итд. Генолошки знаци (бајка, комедија, игра) у насловима и поднсловима функционишу не само као знаци повезаности са жанровским моделом, већ и као симптоми жанровске свести (Јуван 2013: 234). Ближе жанровске ознаке које су одредили сами аутори могу бити корисне упуте у аналитичком процесу. Мисли се на одређења које је Александар Поповић дао уз Пепељугу („бајка за играње у три чина”), или Љубиша Ђокић уз Биберче („по народној приповетки позоришни комад за децу у стиховима у четири чина са прологом”). Игор Бојовић уз Мачора у чизмама даје објашњење (наравно у иронијском кључу) да је реч о „херојској комедији”. Бранко Милићевић дефинише свој комад Мачка у чизмама као „комедију ситуације и забуне, можда чак водвиљ” а Бошко Трифуновић Бајку о изару и пастиру као „позоришну игру у три чина за омладину”. Све су то, могло би се рећи ,једнократне дефиниције” (Маркјевич 1974: 134). „Позоришни плакат захтева од драмских дела дефиницију врсте, али се на њему најчешће јавља или дефиницја рода, обично назив 'драма' или 'комад' или једнократан назив” (Маркјевич 1974: 135). То је уочљиво и у драмским делима за децу Љубивоја Ршумовића, у стилском одређењу које даје писац: Успавана лепотиияа је „романтична комедија”, а драма У изара Тројана козје уши, „приручна комедија која се бави митологијом и психологијом љубави са посебном пажњом према ђавологији детињства”. Ршумовић хоће да „завара” читаоца. У поднаслову Успаване ле-

26 За овај поступак у нашој књижевности за децу користе се и термини „разбајчивање” (Ц. Ристановић), или „одступница од бајке” (Б. Ј. Провчи), итд. 
потице одређује жанр - романтична комедија. Схему класичне бајке (мотив, тему, сиже) Ршумовић је поступком ироније стваралачки надоградио и обликовао драмску структуру вишеслојног значења.

У најновијем периоду у драмским текстовима за децу примећују се обележја постмодернистичке интерпретације, што није ништа необично јер низ писаца ствара истовремено за децу и за одрасле читаоце. Постмодернистичке црте у драмској књижевности за децу су: језичка игра, заиграност, иронизација, пародија класичне књижевности и баштине; хиперболичност; цитатност (интертекстуалност); везе с масовном културом. Српски драмски писци за децу траже у бајци, народним приповеткама и другим усменим прозним врстама најснажнији ослонац и у првим десетлећима новог миленијума, као што су то чинили и њихови претходници у другој половини двадесетог века.

Истовремено, али у мањем обиму, у изградњи драмских дела за децу аутори употребљавају и поезију (Плави зец Сташе Копривице по мотивима песме Душана Радовића, Змајовини пангалози Иване Димић, и др.), прилагођавају и адаптирају за позориште популарне романе, филмове и анимиране филмове (Пипи дуга чарапа Астрид Линдгрен, Хобит Џ. Р. Р. Толкина, итд.). У најкраћем, не постоје књижевне врсте којима позориште за децу не може прићи. На сценама српских специјализованих позоришта за децу појављују се и „самоникла”, аутентична, оригинална драмска дела која се опиру строгој класификацији.

Кад је реч о жанровима, стилским поступцима, књижевним проседеима, у српској драмској књижевности за децу уочавају се пародија, сатира и парабола као владајући облици. Сатира се испољава у традиционалном комедијском облику: комедија за децу Четири прасета Бранка Милићевића је политичка сатира у алегоријском облику, а Успавана лепотица, истог аутоpa, карактеристична је по томе што има јасну, утилитарну намеру - да деци приближи класичну музику и балет, а и поред тога има велику драматуршку вредност. Овде, дакле, Милићевић не следи ток оригиналне бајке него је то више „балетско-класична, мало пародична” комедија за децу. У драми Ивища и Марица и опака старица Мирјане Ојданић уочава се парабола, ауторица овај комад жанровски ближе одређује на следећи начин: „хорор комедија за децу или игра са подсвешћу”. То је двослојна драма, односно са паралелном радњом: на јави играју глумци, а у сну лутке. Хумор је одлика и других преобликованих бајки Мирјане Ојданић (обрада народне приповетке Девојка цара надмудрила или Кокошке умиру од љубави. Мила Машовић се у изградњи драме Гуливерово путовағе служи сонговима као везивним драмским ткивом све до величанствене певљиве апотеозе. Савременост, хумор и иронија одлика су и драматуршког поступка Милене Деполо у, како је она ближе одређује, басни „са два краја” Цврчак и мрав. Ауторка најпре „укида” илузију и у маниру класичне драме уводи приповедача који најдиректније саопштава да се радња догађа у Позоришту лутака „Пинокио”. У истој су функцији и сонгови, духовити и непосредни помоћу којих се наравоученије разблажује. Маја Пелевић је употребила садржај неколико Езопових басни као грађу за мјузикл за децу Чудне љубави. Тако је настала једна динамична, распева- 
на, поетска нежно-сурова драмска форма. Милена Богавац је творац драмске грађе за реализацију специфичног мјузикла за децу. Она се послужила славним романом Пипи Дуга чарапа и изградила „хип хопмјузикл за паметну децу". Богавчева је и аутор Бајке о електрицитету или Часа физике код професора Сијалице, „брехтовске комедије едукативног карактера инспирисане животом Николе Тесле” жанровски одређене као „сценарио мултимедијалне представе за децу", дајући тиме примат техници драме у односу на њену драматуршку, односно књижевну вредност.

Српска драмска књижевност за децу представља, истодобно, жанровски и генетички скуп дела, између којих се плете сложена мрежа стварних сродстава (подражавањем или настављањем), тематских сродности, интеракција међу делима. Жанровске категорије (васпитно-образовни утицај, маштовитост, непосредност, сликовитост, осећајност - дистинктивне одлике књижевности за децу које се могу приписати и драми за децу, стил) непрестано повезује критику поједиачних дела са разматрањем целе групе дела, више или мање ширих размера. Српску драмску књижевност за децу карактерише и архитекстуалност - укљученост књижевног текста у „архитекст , тј. у мрежу која га превазилази и окружује, исплетену од типова дискурса из којих и сам извире” (Јуван 2013: 157). У архитекстуалност уврштени су имплицитни односи текстова према жанровима, тематским формалним и модалним репертоарима, све до фонда стилских регистара и фигура (Јуван 2013: 157).

Детекција жанра драмских текстова за децу је изузетно комплексан и осетљив задатак. Сваки је текст истовремено конкретизација одређеног жанра и одступање у односу на тај жанр, који представља идеални модел књижевног облика. У савременој драмској књижевности мноштво је облика који се преплићу или додирују тако да је веома тешко утврдити линије жанровског разграничења. Инетеретекстуалност је карактеристика знатног броја драмских текстова за децу која се очитује у употреби, преобликовању, преуређивању, преосмишљавању и превредновању постојећег лексичког материјала и конвенција (Јуван 2013: 191). Утврђивање, идентификација жанра драме за децу у овом раду спроведена је првенствено у „практичне, оријентацијске сврхе" (Бити 2000: 594). Питања жанра мобилишу истраживаче у подручју историје књижевности и књижевне критике. Будући да историја драмске књижевности за децу у српској књижевности још није конституисана, остаје да књижевна критика валоризује подручје драмске књижевности и својим дејством утиче на њено даље, чвршће конституисање.

\section{ЛИТЕРАТУРА}

Бити 2000: V. Biti, Pojmovnik suvremene književne i kulturne teorije, Zagreb: Matica hrvatska.

Велек, Ворен 1985: R. Velek, O. Voren, Teorija književnosti, Beograd: Nolit. Гиљен 1980: K. Giljen, Književnost kao sistem, Beograd: Nolit. 
Женет 2002: Ž. Ženet, Figure V, Novi Sad: Svetovi.

Јуван 2013: M. Juvan, Intertekstualnost, Novi Sad: Akademska knjiga.

Калер 1975: J. Culler, Structuralist poetics: Structuralism, linguistics, and the study of literature, London: Routledge \& Kegan Paul.

Маркјевич 1974: H. Markjevič, Nauka o književnosti, Beograd: Nolit.

Марковић 2003: S. Ž. Marković, Šta je to drama za decu, Detinjstvo, 3-4, str. 6.

Млађеновић 2009: M. Mlađenović, Odlike dramske bajke, Novi Sad: Sterijino pozorje.

Солар 2007: M. Solar, Književni leksikon, Zagreb: Matica hrvatska.

Тодоров 1986: C. Todorov, Poetika, Beograd: Filip Višnjić, Zavod za izdavačku delatnost.

\author{
Milivoje V. Mlađenović
}

CHILDREN'S DRAMA IN THE GENRE SYSTEM

\title{
Summary
}

This paper analyses and classifies children's drama in the genre system. The analysis and the classification stem from the definition of a children's drama as a structure which is intended and suited to children of different age, according to its language and structure. The classification is made according to the form of the dialogue, type and method to the events and actions shown in the play, age and the aesthetic effect on the audience. The identification and typologisation of children's plays also included different indicators related to the nature of the plots and characters in the play: length of the play, purpose, number of characters as well as indicators related to media in which they appear (a theatre play, puppet play, radio play, TV play, movie, musical, etc.). This paper shall highlight specific forms of children's plays such as adapted pieces of prose and poetry. However, these are not merely adaptations of a specific text to a script, they are a new play. In that regard, special focus will be put on the re-shaping of a fairy-tale model as a special form of adaptation and dramatization. The paper concludes that the study of children's plays, its development, classification and evaluation are not in line with the status this genre gas in children's literature and that lags behind in terms of the critical reception of other literary fields. 